\title{
DESAIN SISTEM PEMBELAJARAN BLENDED LEARNING : UPAYA PENINGKATAN KUALITAS PENDIDIKAN DI INDONESIA
}

\author{
Ulfia Rahmi* \\ *Program Studi Teknologi Pendidikan, Fakultas Ilmu Pendidikan, Universitas Negeri \\ Padang, Indonesia
}

\begin{abstract}
ABSTRAK
Tujuan penulisan artikel ini adalah untuk menjelaskan pentingnya mendesain sistem pembelajaran blended learning dengan mempertimbangkan komponen-komponen pembelajaran. Pentingnya desain sistem pembelajaran dilakukan karena pembelajaran merupakan inti pendidikan, ketika memperbaiki kualitas pendidikan maka tingkatkan kualitas pembelajaran. Desain sistem pembelajaran inilah yang menjadi salah satu upaya dalam meningkatkan kualitas pembelajaran. Pembelajaran saat ini yang sedang digandrungi adalah pembelajaran berbasis teknologi menggunakan internet. Pembelajaran yang menggunakan internet melahirkan sistem pembelajaran yang lebih fleksibel, dapat dilakukan dimana saja dan kapan saja (online learning). Namun, di Indonesia belum dapat dilakukan sepenuhnya karena keterbatasan sarana dan sumber daya untuk melakukan fully online learning. Perlu mempertahankan pertemuan tatap muka dengan mengombinasikan dengan online learning yaitu blended learning, sehingga potensi peserta didik dapat dikembangkan. Oleh sebab itu, agar blended learning dapat diimplementasikan dibutuhkan desain sistem pembelajaran. Sistem terdiri dari banyak bagian yang saling berhubungan satu dengan yang lainnya. Ketika satu komponen tidak berjalan sesuai perannya maka tujuan dari sistem juga akan terganggu, misalnya tujuan pembelajaran, materi, metode dan media, peserta didik, pendidik dan evaluasi. Komponen pembelajaran inilah yang saling melengkapi dalam mencapai tujuan desain sistem pembelajaran yaitu menciptakan suasana belajar yang kondusif agar peserta didik secara optimal mengembangkan potensi diri. Artinya, desain sistem pembelajaran blended learning yang dilakukan adalah mendesain sebuah pembelajaran dengan mempertimbangkan komponen pembelajar, tidak hanya terfokus pada salah satu komponen saja.
\end{abstract}

Kata kunci: blended learning, desain, sistem pembelajaran

\section{A. PENDAHULUAN}

Selama ini kita selalu mengeluhkan rendahnya kualitas pendidikan di Indonesia, tidak tersentuhnya setiap warga negara oleh pendidikan dan semakin banyaknya jumlah pengangguran. Beranjak dari isu Depdiknas 2005 untuk meningkatkan pendidikan, perlu dilakukan a) pemerataan dan perluasan, b) peningkatan mutu, relevansi dan daya saing, c) penguatan tata kelola, akuntabilitas dan pencitraan publik. Jika diklasifikasifikaskan menjadi tiga permasalahan besar, Menurut Nanang [1] pendidikan Indonesia pada dasarnya terkover oleh tiga permasalahan yaitu; kualitas, pemerataan dan relevansi. Ketiga permasalahan tersebut saling terkait, ketika fokus memecahkan masalah kualitas, pemerataan dan relevansi cenderung terabaikan, begitu pula sebaiknya. Sehingga, dibutuhkan upaya peningkatan kualitas sumber daya manusia untuk meminimalisir permasalahan-permasalah tersebut. Ternyata, dalam meminimalisir 
permasalahan tersebut tidak semudah membalikkan telapak tangan.. Contohnya beberapa tahun yang lalu di Indonesia diselenggarakan pendidikan Sekolah Berstandar Internasional (SBI) untuk meningkatkan mutu pendidikan Indonesia agar mampu bersaing di kancah internasional. Masalah yang muncul saat itu adalah tidak tersebar secara merata sarana dan prasarana di sekolah-sekolah karena terfokus pada SBI. Kritikan yang muncul untuk SBI adalah terjadinya diskriminasi antara si kaya dan si miskin. Orang yang lebih mampu membiayai pendidikan anaknya di SBI lebih berkesempatan mendapatkan layanan pendidikan yang lebih baik. Sedangkan kalangan menengah ke bawah yang terkendala pada biaya terbatas kesempatannya untuk menikmati fasilitas pendidikan seperti yang ada pada SBI. Fasilitas SBI diatur dalam UU nomor 20 tahun 2003 pasal 50 ayat 3 [2] bahwa sarana dan prasarana SBI wajib setiap ruang kelas dilengkapi sarana pembelajaran berbasis TIK, perpustakaan dilengkapi dengan sarana digital, memberikan akses ke sumber pembelajaran berbasis TIK di seluruh dunia, dilengkapi dengan ruang multimedia, ruang unjuk seni dan budaya, fasilitas klinik, fasilitas olahraga dan lainlain. Namun pada sekolah biasa tidak ada aturan yang mewajibkan sarana minimal. Kelengkapan sarana inilah yang menyebabkan biaya pendidikan pada SBI tinggi, sehingga berdampak pada biaya tambahan yang harus dikeluarkan oleh orang tua.

Sebaliknya, ketika mengupayakan meminimalisir masalah pemerataan, pada saat yang sama juga muncul masalah kualitas. Kita masih ingat bahwa sekolah dasar Inpres dan sekolah Satu Atap diselenggarakan dalam upaya pemerataan pendidikan di Indonesia, agar warna negara yang tinggal di daerah yang sulit dijangkau mendapatkan hak mereka untuk menempuh pendidikan. Upaya pemerataan tersebut patut diberi apresiasi karena ketika upaya tersebut tidak dilakukan maka sampai sekarang barangkali daerah-daerah terpencil dan sulit dijangkau belum memiliki sekolah. Namun di sisi lain, dalam pelaksanaan pendidikan di sekolah dasar Inpres dan sekolah Satu Atap kualitas jangan ditanya. Di sekolah Satu Atap misalnya, berdasarkan survei di SMP satu atap Kecamatan IV Koto Aua Malintang, Kabupaten Padang Pariaman, sekolah terdiri dari sekolah dasar dan sekolah menengah pertama berada pada satu lokasi, ternyata pendidiknya juga satu untuk semua. Terakhir, masalah ketiga adalah relevansi. Keluhan mengenai jumlah pengangguran yang semakin meningkat erat kaitannya dengan relevansi pendidikan yang dilalui oleh peserta didik. Sesungguhnya, permasalahan relevansi ini sudah muncul sejak masa orde baru. Waktu itu diminimalisir dengan program mix and match (Tilaar [3]). Program mix and match ini sebagai upaya untuk menyelaraskan kompetensi yang dimiliki peserta didik ketika menyelesaikan pendidikan dengan kompetensi yang dibutuhkan di dunia kerja. Program tersebut tidak berjalan maksimal, sehingga sampai sekarang permasalahan relevansi masih betah bertahan sebagai salah satu dari permasalahan pendidikan di Indonesia. Buktinya,

Berbagai upaya lain sudah dilakukan pemerintah, masyarakat dan sekolah, namun karena beberapa faktor seperti pergantian pimpinan, arus politik, keamanan, kesejahteraan sampai pada cara pandang masyarakat mempengaruhi permasalahan tersebut sehingga belum tuntas sampai sekarang. Peningkatan kualitas, pemerataan dan relevansi yang 
menjadi permasalahan utama pendidikan di Indonesia sesungguhnya dapat diatasi dengan meningkatkan kualitas pembelajaran. Hal ini merujuk pada pendapat Nanang [1] bahwa peningkatan mutu, relevansi, dan daya saing dilakukan dengan peningkatan kualitas pembelajaran melalui pengembangan kurikulum, metode pembelajaran dan sistem penilaian. Meskipun sebuah kelas (dalam kegiatan pembelajaran) merupakan tataran mikro dalam pendidikan yang begitu luas, namun pembelajaran menentukan proses dan hasil selanjutnya karena menurut Cloud [4] pendidikan dilakukan untuk masa depan yang berkelanjutan. Hasil pembelajaran pada tingkat dasar sebagai modal untuk pendidikan menengah, dan pendidikan menengah untuk modal pendidikan tinggi. Hal inilah yang menyebabkan proses pendidikan harus terus menerus dan berkelanjutan. Secara eksplisit, proses pendidikan itu dapat dilihat pada proses pembelajaran sehingga pembelajaran menjadi inti pendidikan. Oleh sebab itu, ketika ingin meningkatkan kualitas pendidikan hal utama yang harus dilakukan adalah meningkatkan kualitas pembelajaran. Sehingga dengan peningkatan kualitas pembelajaran, relevansi dan pemerataan ikut serta meningkat. Pendidikan yang berkualitas dapat dilakukan dengan mewujudkan pembelajaran bermakna dan pembelajaran yang dapat menanamkan nilai-nilai yang peserta didik butuhkan di masa mendatang. Misalnya penanaman nilai-nilai dari pembakaran hutan ilegal. Dalam proses pembelajaran peserta didik tidak saja dituntut mampu mengucapkan akibat dari menebang hutan sembarangan, tetapi mampu memaknai materi. Para penebang hutan sekarang mereka mampu mengungkapkan akibat dari menebang hutan secara ilegal namun mereka tidak melakukan yang mereka ucapkan. Mereka hanya mampu verbalisme tanpa memaknai pesan dari menebang hutan secara ilegal.

Ketika pembelajaran menjadi inti dari pendidikan, maka pembelajaran pada intinya merupakan perwujudan suasana belajar dalam upaya mengembangkan potensi peserta didik dalam upaya meningkatkan kualitas sumber daya manusia. Transfer pengetahuan akan terjadi dalam proses interaksi sosial antara peserta didik dan pendidik sehingga hasil interaksi pendidikan tersebut akan membentuk tingkah laku yang berpendidikan pula. Cara terbaik dalam membelajarkan itu dengan mencontohkan melalui interaksi antara pendidik dengan peserta didik, bukan sekadar justifikasi. Hal ini sebenarnya juga termaktub dalam UU nomor 20 tahun 2003 [2] tentang Sistem Pendidikan Nasional bahwa pendidikan merupakan usaha sadar dan terencana untuk mewujudkan suasana belajar dan proses pembelajaran agar peserta didik secara aktif mengembangkan potensi dirinya untuk memiliki kekuatan spiritual keagamaan, pengendalian diri, kepribadian, kecerdasan, akhlak mulia serta keterampilan yang diperlukan dirinya, masyarakat, bangsa dan negara. Oleh sebab itu, untuk memecahkan permasalahan pendidikan, tersebut perlu peningkatan kualitas pembelajaran melalui sebuah rancangan sistem pembelajaran. Sistem pembelajaran inilah yang membantu pendidik menciptakan pembelajaran berkualitas. Rancangan sistem pembelajaran yang sedang digandrungi saat ini adalah rancangan sistem pembelajaran yang berbasis teknologi karena relevan dan sangat disukai oleh anak-anak usia sekolah.

Kehadiran teknologi komputer dan jaringan di Indonesia, telah mempengaruhi proses belajar di ruang kelas. Dengan 
munculnya teknologi ini belajar bisa saja dilakukan dimana saja. Jika sebelum teknologi komputer dan jaringan digunakan di Indonesia, orang-orang mengirim modul pembelajaran untuk belajar mandiri dalam bentuk printout, maka pengoptimalan komputer dan internet dalam pembelajaran dapat mempermudah distribusi modul menggunakan email atau dapat didownload pada website tertentu yang sudah disediakan. Menurut Smaldino [5], istilah pembelajaran berbasis komputer yang menggunakan jaringan internet disebut dengan online learning. Meskipun online learning menawarkan media yang bervariasi dan fleksibel waktu serta tempat, ternyata pembelajaran ini memiliki kelemahan-kelemahan tertentu (Bersin [6]). Hal ini melahirkan pembelajaran yang mencampurkan pembelajaran online dengan pembelajaran tatap muka yang disebut dengan blended learning. Pencampuran tersebut dengan mengombinasikan kelebihan pertemuan tatap muka dengan kelebihan online learning dan meminimalisir kekurangan pertemuan tatap muka dengan online learning. Berdasarkan perkembangan tersebut, maka saat ini fokus pengembangan sistem pembelajaran adalah sistem pembelajaran yang berbasis blended learning. Sistem pembelajaran blended learning seperti apa yang dapat meningkatkan interaksi pendidikan antara peserta didik dan pendidik dalam upaya mengembangkan potensi peserta didik sehingga ketiga masalah pokok pendidikan di Indonesia terpecahkan.

\section{B. PEMBAHASAN}

1. Desain Sistem Pembelajaran

Desain merupakan satu dari lima ranah keilmuan Teknologi Pendidikan di samping pengembangan, pemanfaatan, pengelolaan dan evaluasi. Kawasan desain menurut Seels [7] adalah proses untuk menentukan kondisi belajar dengan tujuan agar tercipta strategi dan produk pada tingkat makro, seperti program dan kurikulum, dan pada tingkat mikro, seperti pelajaran dan modul. Dalam Teknologi Pendidikan, ranah desain meliputi desain sistem pembelajaran, desain pesan, strategi pembelajaran dan karakteristik pembelajar. Ranah desain pada Teknologi Pendidikan ini memiliki kaitan erat dengan pendidikan yang dimaksud oleh UU Sisdiknas [2] bahwa pendidikan sebagai usaha sadar dan terencana untuk menciptakan suasana belajar dan proses pembelajaran. Untuk mencapai pendidikan seperti yang disebutkan dalam UU tersebut, Teknologi Pendidikan sangat berperan dalam menciptakan suasana belajar dan proses pembelajaran melalui ranah desain ini, yaitu dengan mendesain sistem pembelajaran melalui model pengembangan 4D. Model ini mencakup Define, Design, Develop and Disiminate (Thiagarajan [8]). Menggunakan model inilah dikembangkan berbagai pembelajaran termasuk blended learning

Desain sistem pembelajaran sangat tepat karena sebagaimana yang dibahas sebelumnya, bahwa inti pendidikan itu terletak pada pembelajarannya. Dengan mendesain sistem pembelajaran berarti berupaya meningkatkan interaksi peserta didik dan pendidik untuk mengembangkan potensi mereka. Karena sistem merupakan suatu kesatuan yang utuh dan terstruktur, menurut Dewi Salma [9] desain sistem pembelajaran juga dilengkapi oleh komponen-komponen pembelajaran dan tersusun secara terstruktur. Desain sistem pembelajaran menurut Seels [7] merupakan suatu prosedur yang terorganisir, meliputi: langkah-langkah di antaranya: a) penganalisisan, yaitu proses perumusan apa 
yang akan dipelajari; b) perancangan, yaitu proses penjabaran bagaimana cara mempelajarinya; c) pengembangan, yaitu proses penulisan atau produksi bahan-bahan pelajaran; d) pelaksanaan , yaitu pemanfaatan dan strategi; e) penilaian, yaitu proses penentuan ketepatan pembelajaran. Dalam desain sistem pembelajaran, proses sama pentingnya dengan produk, sebab kepercayaan atas produk berlandaskan pada proses. Apapun model pembelajaran yang dipilih, lima langkah ini menjadi inti sistem desain pembelajarannya. Dengan mengikuti prosedur tersebut, dapat tercipta suasana belajar dan proses pembelajaran seperti yang termaktub dalam PP nomor 32 tahun 2013 [10] pembelajaran yang interaktif, inspiratif, menyenangkan, menantang, memotivasi peserta didik untuk berpartisipasi aktif, memberikan ruang gerak yang cukup bagi prakarsa, kreativitas dan kemandirian sesuai dengan bakat, minat dan perkembangan fisik serta psikologi peserta didik. Untuk menyelenggarakan pembelajaran seperti yang disebutkan dalam PP tersebut, Richey, Klein dan Tracey [11] mengingatkan bahwa perlu beberapa pengetahuan dasar dalam desain pembelajaran.

Sistem pembelajaran sangat berperan dalam mengembangkan potensi peserta didik. Proses tersebut berlangsung karena terdapatnya interaksi antara peserta didik dan pendidik. Ketika interaksi tersebut terjadi dalam konteks pembelajaranpendidikan, maka akan terbentuk perilaku peserta didik. Abizar [12] menjelaskan bahwa skemata atau pengetahuan awal pada diri individu itu terbentuk dan berkembang melalui kematangan, belajar dan pengalaman. Tiga hal tersebut dapat terjadi ketika individu atau peserta didik tertentu melakukan interaksi selama proses pembelajaran, baik dengan pendidik, dengan peserta didik lainnya, media pembelajaran maupun dengan materi pembelajaran. Artinya, untuk mengembangkan potensi peserta didik, yang mereka perlukan adalah interaksi. Seperti yang dikemukakan Shambaugh [13] bahwa desain pembelajaran menangani tentang kebutuhan manusia dalam konteks pembahasan ini kebutuhan belajar, dan manfaat kegiatan desain pembelajaran ini hasil dari interaksi sosial peserta didik dengan peserta didik lainnya. Seperti yang dikemukakan oleh Dewi Salma [9] tentang komponen pembelajaran, maka dalam pembahasan mengenai sistem pembelajaran, proses pengembangan potensi tersebut didukung oleh komponenkomponen sistem pembelajaran, diantaranya tujuan pembelajaran, materi, metode dan media, peserta didik, pendidik dan evaluasi. Jadi, ketika mengembangkan desain sistem pembelajaran, tidak terlepas dari mempertimbangkan komponen tersebut. Karena sistem merupakan suatu kesatuan utuh yang terbentuk dari komponen pembangunnya, seperti yang dikatakan oleh Richey, Klein dan Tracey [14] bahwa sebuah sistem itu terdiri dari banyak bagian yang saling berhubungan satu dengan yang lainnya. Oleh sebab itu, ketika satu komponen tidak berjalan sesuai perannya maka tujuan dari sistem juga akan terganggu. Sistem pembelajaran ini jika dianalogikan ke dalam sistem lain seperti sebuah mobil. Meskipun sebuah pentil yang kecil sekalipun pada sebuah mobil tidak berfungsi atau tidak ada maka larinya mobil tidak optimal. Jika dijadwal ingin sampai pukul 8, maka tanpa pentil bisa sampai di tempat tujuan pukul 10. 


\section{Blended Learning}

Blended learning, menurut Smaldino

[5] merupakan pencampuran dan pengaturan pembelajaran yang divariasikan agar sesuai dan tepat untuk memenuhi kebutuhan belajar peserta didik. Sejalan dengan itu, menurut Graham [15], blended learning adalah sebuah sistem yang mengombinasikan pembelajaran tatap muka dan pembelajaran berbantuan komputer dengan mengintegrasikan penggunaan media berbasis komputer untuk membantu penyampaian materi ajar. Sedangkan Watson [16] merinci pengertian blended learning sebagai kegiatan pembelajaran yang mengombinasikan komponen terbaik dari online learning dengan pendidikan tatap muka. Secara garis besar, media berbantuan komputer sangat luas sedangkan online learning merupakan pembelajaran berbantuan komputer melalui jaringan. Dari tiga pendapat ini dapat disimpulkan bahwa pembelajaran blended merupakan campuran tentang pembelajaran berdasarkan kebutuhan peserta didik, pembelajaran berbantuan komputer dan pembelajaran online learning.

Berbeda dengan apa yang dikemukakan di atas, Rossette [17] mengatakan bahwa blended learning itu adalah mencampurkan pendekatan yang berbeda, misalnya formal and informal learning, face-to-face and online learning experience, directed paths and reliance on self-direction or digital references and collegial connections. Pendapat Smaldino [5], Graham [15], Watson [16] dan Rossette [17] mengandung satu makna mencampur untuk menjelaskan masing-masing pengertian blended. Namun Bersin [6] mengemukakan bahwa blended learning is not a new concept, but the tools available to us today are now. Artinya, blended learning bukanlah konsep baru karena jauh sebelum ada pencampuran pembelajaran online dan tatap muka, sudah ada pencampuran pembelajaran tatap muka dengan video langsung berbasis satelit, pencampuran pembelajaran tatap muka dan Komputer Personal (PC) menggunakan CD-ROM dan baru beralih ke pencampuran pembelajaran tatap muka dan online learning ketika internet mulai dikenal banyak orang. Di sini Bersin [6] menegaskan bahwa pencampuran yang dilakukan dalam kegiatan tatap muka adalah pencampuran dengan alat baru yang tersedia saat ini. Jika dilihat kekiniannya, alat terbaru berbantuan komputer yang ada saat ini adalah online seperti yang diungkapkan oleh Watson [16]. Dengan begitu dapat dikatakan blended learning merupakan pencampuran antara pembelajaran tatap muka dan pembelajaran berbantuan komputer yang ada pada saat itu (today). Pada intinya, pembelajaran online merupakan pembelajaran yang didukung oleh infrastruktur pendukung dengan memanfaatkan kemajuan teknologi komputer dan jaringan internet. Ini adalah sebuah sistem yang dapat memfasilitasi peserta didik untuk belajar lebih luas, lebih banyak dan lebih bervariasi, sehingga peserta didik bisa belajar kapan saja dan dimana saja.

Melalui blended learning, dengan keleluasaan dan pilihan media yang bervariasi dapat meningkatkan interaksi peserta didik untuk memberikan mereka pengalaman belajar. Pandangan Behaviorisme (stimulus dan respons, S-R) yang dikemukakan Ivan $\mathrm{P}$ Pavlov, B. F. Skinner, J. B. Watson, C. L Hull, Guthrie dan Thorndike dalam Gredler [18], menganggap bahwa pengalaman belajar akan terjadi ketika peserta didik diberikan stimulus melalui berbagai media pembelajaran berbasis online. Stimulus- 
stimulus (S) dari media tersebut membantu dan mendorong peserta didik untuk memberikan respons (S) sehingga mereka terbiasa untuk belajar. Dalam desain sistem blended learning bagaimana mendesain pembelajaran yang memberikan stimulusstimulus melalui komponen pembelajaran untuk meningkatkan respons peserta didik. Sedangkan menurut pandangan Kognitivisme yang dikemukakan oleh Piaget, dan Jerome Bruner dalam Gredler [18] berpendapat bahwa peserta didik memiliki potensi yang bisa dikembangkan, sehingga untuk membentuk pengalaman belajar dilakukan dengan meningkatkan insight (pemahaman) mereka. Aplikasinya dalam desain sistem blended learning adalah bagaimana mendesain sistem pembelajaran yang dapat mengembangkan kognisi peserta didik untuk meningkatkan pemahaman mereka.

Dari dua pandangan teori belajar Behaviorisme dan Kognitivisme tersebut, pengalaman belajar melalui interaksi dapat ditingkatkan melalui kegiatan pembelajaran. Jika dalam Behaviorisme kegiatan pembelajaran dengan memberikan stimulus-stimulus kepada peserta didik, maka dalam Kognitivisme kegiatan pembelajaran dengan memberikan mereka kesempatan untuk mengeksplor sendiri pengetahuan yang mereka butuhkan. Kedua hal ini dalam desain sistem blended learning bukan hal yang bertolak belakang, namun saling melengkapi. Artinya dengan meningkatkan resonansi aplikasi dua pandangan teori belajar yang berbeda tersebut, dapat mengoptimalkan pengalaman belajar itu sendiri. Kedua pandangan ini dapat mengoptimalkan pembelajaran blended, misalnya pemberian tugas melalui online learning dan pembahasan serta diskusinya pada pertemuan tatap muka. Hal yang demikian praktik behaviorisme, pemberian tugas merupakan stimulus dan tugas yang ditulis merupakan respons. Sedangkan pembahasan dan diskusi merupakan proses kognitif karena selama proses itu berlangsung terjadi proses pemaknaan. Misalnya, pemberian stimulus dalam blended learning melalui website pembelajaran yang dirancang khusus untuk pembelajaran dengan konten materi ajar yang sudah disusun sedemikian rupa, dan kemudian dengan wadah website pembelajaran dilengkapi dengan google peserta didik dapat mengeksplor berbagai pengetahuan lain yang relevan dengan tujuan pembelajaran.

Proses diskusi inilah yang membentuk interaksi sosial. Menurut Sudardja [19] interaksi sosial merupakan kata kunci dalam proses pendidikan. Keberhasilan pendidikan ditentukan oleh mutu interaksi tersebut, dengan siapa berinteraksi, pesan yang disampaikan, bagaimana interaksi berlangsung, media dan sara prasarana yang digunakan serta bagaimana dampak dari interaksi tersebut. Oleh sebab itu, diskusi sebagai salah satu bentuk kegiatan belajar (learning activity) menjadi penting dalam mengembangkan potensi peserta didik karena melalui kegiatan tersebut memberikan kesempatan kepada peserta didik untuk berinteraksi dengan lingkungan sosial mereka. Maka, ketika kegiatan belajar terjadi, informasi yang mereka dapatkan di ruang kelas bukan sekadar menjadi catatan rapi bagi peserta didik dan disimpan di rumah, namun agar mereka dapat secara aktif mengembangkan potensi diri. Dengan learning activity, informasi yang peserta didik terima di ruang kelas ataupun belajar di website dapat menjadi pengetahuan. Ketika peserta didik yang sudah berbekal pengetahuan ditingkatkan lagi dengan learning activity, 
maka pengetahuan tersebut akan menjadi pengalaman belajar bagi mereka. Selanjutnya, pengalaman yang mereka miliki tersebut dikembangkan lagi melalui learning activity, maka akan terbentuk kompetensi pada diri individu. Proses tersebut dapat diilustrasikan seperti gambar di bawah ini:

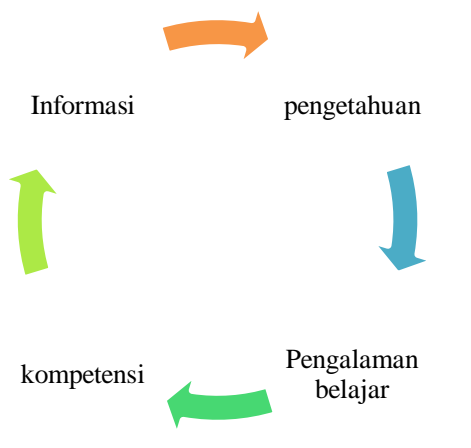

Gambar 1. Siklus Kegiatan Belajar

Berdasarkan ilustrasi tersebut dapat dimaknai bahwa dari informasi, pengetahuan, pengalaman belajar sampai kompetensi merupakan suatu siklus yang terjadi akibat kegiatan belajar. Menjadi sebuah siklus karena belajar itu tidak pernah berakhir. Ketika peserta didik sudah mencapai kompetensi pada satu tujuan pembelajaran, bukan berarti peserta didik berhenti sampai di situ. Namun kompetensi yang sudah dimiliki akan menjadi pengetahuan awal untuk mencapai kompetensi-kompetensi selanjutnya. Agar siklus tersebut berjalan sebagaimana mestinya, proses atau siklus dibantu oleh komponen-komponen pembelajaran pada setiap kegiatan belajar (learning activity). Seperti yang dijelaskan Santrock [20] bahwa seseorang ketika mengaplikasikan pengalaman dan pengetahuan yang dimilikinya untuk mempelajari dan memecahkan masalah dalam situasi baru. Artinya, materi yang dipelajari peserta didik sebelumnya dan saat ini diharapkan dapat menjadi modal awal mereka untuk memecahkan masalah di masa mendatang. Siklus transfer belajar seperti itu perlu dipertahankan, sehingga ilustrasi siklus pembelajaran yang dilengkapi komponen pembelajaran akan menjadi seperti ilustrasi berikut ini:

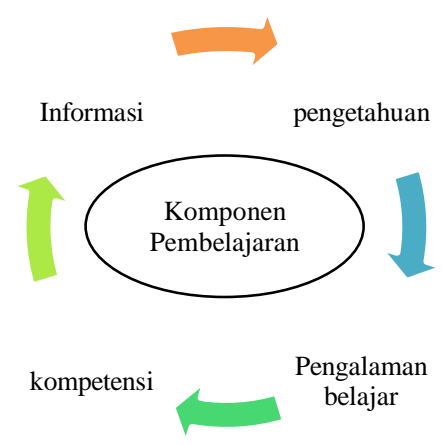

Gambar 2. Posisi Komponen Pembelajaran dalam Siklus Kegiatan Belajar

Gambar 2 dapat dimaknai bahwa dalam siklus pembelajaran melalui kegiatan pembelajaran, untuk mengembangkan informasi menjadi pengetahuan, pengetahuan menjadi pengalaman belajar dan pengalaman belajar menjadi kompetensi, untuk setiap kegiatan pembelajaran tidak mungkin tidak melibatkan komponen pembelajaran di dalamnya. Menurut Richey, Klein dan Tracey [14] sebuah sistem, desain sistem pembelajaran dari komponen penyusunnya saling berinteraksi, yaitu berhubungan secara aktif dan saling mempengaruhi. Misalnya menentukan metode pembelajaran merujuk pada tujuan pembelajaran, karakteristik peserta didik, materi, serta evaluasi yang akan digunakan. Begitu pula ketika menentukan evaluasi pembelajarannya merujuk pada tujuan pembelajaran, materi pembelajaran, dan metode pembelajaran. Dalam konteks pembahasan ini, bagaimana interaksi komponen blended learning. 
3. Penelitian dalam Desain Blended Learning

Berdasarkan pembahasan di atas, maka sangat penting dilakukan riset dalam bidang desain sistem blended learning. Riset dalam desain sistem pembelajaran merupakan riset yang bergerak dalam bidang pendidikan, terkonsentrasi pada bidang Teknologi Pendidikan. Yaitu risetriset yang memecahkan permasalahan pendidikan melalui sentuhan ilmu Teknologi Pendidikan. Dalam artian, memecahkan permasalahan belajar menggunakan teknologi. Teknologi bagi seorang Teknolog Pendidikan tidak sebatas teknologi komputer, internet dan perangkat mobile lainnya. Namun bagi seorang Teknolog Pendidikan segala upaya untuk menyelesaikan masalah belajar (Yusufhadi [21]) dapat dilakukan melalui teknologi; berupa perkembangan teknologi (alat) untuk pengembangan media pembelajaran dan teknologi non alat untuk pengembangan metode-metode pembelajaran. Riset mengenai desain sistem blended learning berkenaan dengan komponen yang membangun sistem tersebut, artinya ketika melakukan riset yang berhubungan dengan desain sistem pembelajaran akan melibatkan seluruh komponen pembelajaran, yaitu tujuan, materi, media, metode/strategi, pendidik dan peserta didik serta evaluasi pembelajaran.

Riset mengenai desain sistem blended learning sangat penting dilakukan karena kebutuhan akan blended learning itu sendiri. Berbagai penelitian yang dilakukan, seperti Bersin [6], Kurniawati [22], Luhde Irin Pradnyawati, I Nengah Suparta, dan Sariyasa [23], Alwen dan Ulfia [24]. Hasil penelitian membuktikan bahwa saat ini, dengan perkembangan teknologi bukan saja berdampak pada komunikasi sosial saja, namun juga pada komunikasi pembelajaran. Artinya interaksi pembelajaran dipengaruhi oleh perkembangan teknologi pada saat ini agar pembelajaran yang terjadi bersifat kontekstual. Anak usia sekolah sangat menyukai dan tertarik dengan perkembangan teknologi. Bagi seorang Teknolog Pendidikan, hal itu dipandang sebagai salah satu upaya untuk menyelesaikan permasalahan belajar karena saat ini masalah belajar menjadi masalah yang cukup sulit dipecahkan. Masalah belajar yang dihadapi sekarang itu adalah peserta didik bosan dengan suasana belajar dan proses pembelajaran yang biasa mereka lakukan, dan peserta didik membutuhkan media pembelajaran yang bervariasi dan menarik seperti mereka membutuhkan sosial media.

Sehubungan dengan hal itu, riset dalam desain sistem blended learning juga urgen dilakukan mengingat definisi pendidikan yang disampaikan dalam UU nomor 20 tahun 2003 [2] bahwa pendidik merupakan usaha sadar dan terencana untuk mewujudkan suasana belajar dan proses pembelajaran. Kemudian urgensi riset ini dilakukan juga berkaitan erat dengan PP nomor 32 tahun 2013 [10] bahwa proses pembelajaran itu harus dilakukan secara interaktif, inspiratif, menyenangkan, menantang, memotivasi peserta didik untuk berpartisipasi aktif, memberikan ruang gerak yang cukup bagi prakarsa, kreativitas dan kemandirian sesuai dengan bakat, minat dan perkembangan fisik serta psikologi peserta didik. Dan secara teoretis seperti yang John Dewey katakan dalam Smaldino [5] bahwa peserta didik belajar banyak melalui learning by doing. Secara yuridis dan teoretis pendidikan dapat dilakukan melalui blended learning dan learning by doing untuk membentuk interaksi bermedia dan interaksi 
interpesonal/ interaksi sosialnya. Ketika hal itu terjadi dalam kegiatan pembelajaran maka akan dapat dikembangkan informasi menjadi pengetahuan, pengetahuan menjadi pengalaman belajar dan pengalaman belajar menjadi kompetensi. Sehingga dari hal itu diharapkan peserta didik belajar sesuai dengan bakat, minat, perkembangan fisik serta psikologi sesuai dengan tugas perkembangan mereka dalam rangka mengembangkan potensi diri.

Selain urgensi dilakukannya riset dalam desain sistem pembelajaran blended, riset ini sesungguhnya sudah berkembang jauh sebelum teknologi komputer dan internet lahir. Pada masa munculnya televisi, menurut Bersin [6] blended learning dilakukan dengan mengombinasikan pembelajaran tatap muka dengan belajar menggunakan televisi. Kemudian muncul komputer, kombinasi pembelajaran berkembang menjadi kombinasi pembelajaran berbasis komputer (elearning) dengan pembelajaran tatap maka. Dan saat internet juga berpengaruh terhadap pendidikan, pengombinasian pembelajaran terjadi antara pembelajaran menggunakan jaringan internet (online learning) dengan pembelajaran tatap muka. Artinya bahwa blended learning merupakan pengombinasian pertemuan tatap muka dengan kemajuan teknologi yang ada pada saat itu. Berbeda dengan pendapat Smaldino [5] bahwa blended learning merupakan pengombinasian antara pembelajaran synchronous dengan asynchronous. Pada saat ini pembelajaran asynchronous dibantu dengan layanan internet. Penulis memprediksi bahwa internet akan bertahan lama dan belum ada perkembangan yang akan mengalahkan internet. Prediksi yang sama juga dilakukan terhadap desain sistem blended learning, bahwa selama internet dioptimalkan dalam komunikasi pembelajaran selama itu pula blended learning akan bertahan. Dari perjalanan perkembangan teknologi, komunikasi dan pengaruhnya terhadap pembelajaran, juga berdampak pada desain sistem pembelajaran di kelas. Artinya adalah bahwa pembelajaran yang terjadi di kelas jangan terpisah dengan dunia realita di mana peserta didik tinggal. Karena peserta didik sangat jatuh cinta pada hal-hal baru, maka ketika terjadi perkembangan teknologi maka di situ peserta didik mencoba menyatu dengan perkembangan tersebut. Sebagai seorang Teknolog Pendidikan yang ingin menciptakan suasana belajar dan proses pembelajaran seperti yang disebutkan PP nomor 32 tahun 2013 [10] maka tidak ada salahnya mengadopsi teknologi komunikasi sosial dan menjadikannya menjadi teknologi untuk komunikasi pembelajaran.

Oleh sebab itu, agar mampu melakukan riset dalam bidang desain sistem pembelajaran maka untuk menunjang riset tersebut seorang peneliti harus memiliki keahlian, diantaranya berpikir holistik, memahami teori belajar, memahami teori motivasi, teori persepsi, teori pembelajaran, memahami kurikulum, dan kreatif serta inovatif dalam mengembangkan teknologi dan rekayasa pembelajaran. Keahlian yang harus dimiliki oleh seorang peneliti yang pertama adalah a) berpikir holistik dan komprehensif karena akan terjun dalam bidang yang terbentuk dari sebuah sistem yang terdiri dari komponen-komponennya. Jika berpikir sebagian-sebagian atau berpikir terpisah, maka dalam mendesain sistem pembelajaran akan melupakan atau mengabaikan komponen sistem pembelajaran itu sendiri. Karena bekerja dalam sistem berarti memberdayakan komponen-komponen penyusunnya untuk mencapai tujuan dari sistem itu sendiri. Hal 
yang sama juga dikemukakan oleh Atwi [25] bahwa pengembangan pembelajaran merupakan salah satu wujud penerapan teori sistem dalam kegiatan pembelajaran.

Maka ketika salah satu komponen pembelajaran tidak berperan sesuai fungsinya maka tujuan sistem pembelajaran juga sulit untuk dicapai. oleh sebab itu, seorang peneliti dalam bidang desain sistem pembelajaran harus memahami betul teori sistem itu sendiri.

Selanjutnya, keahlian yang harus dimiliki peneliti yang kedua adalah b) memahami teori-teori belajar, karena desain sistem pembelajaran berakar pada teori belajar. Teori belajar utama yang mendukung desain sistem pembelajaran adalah Behaviorisme dan Kongnitivisme (Richey, Klein dan Tracey [14]). Pandangan pakar perilaku seperti P Pavlov, B. F. Skinner, J. B. Watson, C. L Hull, Guthrie dan Thorndike, secara tradisi sangat mendominasi dalam aplikasi desain sistem pembelajaran. Saat ini, desain sistem pembelajaran menekankan pada Kognitivisme sehingga muncullah paradigma pembelajaran yang terpusat pada peserta didik dan banyak juga berdasarkan pada prinsip-prinsip konstruktivisme dalam pengembangan selanjutnya (Seels [7]). Pandangan konstruktivisme beranggapan bahwa pengetahuan yang sudah dimiliki peserta didik sebagai modal awal bagi mereka untuk membangun pengetahuan baru (Suparno [26]). Maka sangat tepat sekali memberikan learning by doing melalui blended learning untuk membentuk pengalaman belajar peserta didik. Kognitivisme lebih tertarik pada perubahan pengetahuan peserta didik dan struktur pengetahuannya (Gredler [18]). Mereka lebih menekankan pada bagaimana peserta didik mengingat informasi. Kognitivisme berpandangan bahwa pengetahuan seseorang dan proses belajar itu sendirilah yang menjadi akar dari penerjemahan yang unik seseorang terhadap dunia. Pandangan ini ditentukan oleh pengalaman seseorang dan penafsirannya terhadap pengalaman itu sendiri. Orientasi Kognitivisme menekankan pada peran konteks, baik konteks pembelajaran maupun konteks situasi berlangsung proses transfer lebih bersifat internal (Santrock) [20]. Kebalikannya dari pendekatan eksternal pakar perilaku bahwa teori perilaku/ Behaviorisme mempunyai perhatian khusus pada kinerja peserta didik sebagai bukti utama bahwa proses belajar sudah dilalui. Terdapat kecenderungan dari hasil penelitian mengenai perilaku yang menekankan pada pengaruh stimulus pada pembelajaran peserta didik. Hal ini mengisyaratkan bahwa dalam pembelajaran yang perlu dilakukan oleh peserta didik itu adalah unjuk kerja karena ketika terjadi perubahan dari tingkah laku peserta didik maka disitulah terjadi proses belajar bagi Behaviorisme. Makanya Behaviorisme sering mendefinisikan pembelajaran sebagai perubahan tingkah laku, dan Kognivisme mendefinisikan pembelajaran sebagai sebuah pemahaman hasil dari proses kognisi (internal).

Selain itu, keahlian yang harus dimiliki oleh peneliti dalam bidang desain sistem pembelajaran blended adalah memahami teori motivasi. Keller [27] juga menyajikan model desain pembelajaran untuk motivasi yang didasarkan pada sejumlah teori lainnya. Modelnya menunjukkan strategi desain yang mencakup empat komponen motivasi: membangkitkan minat, menciptakan relevansi, mengembangkan harapan keberhasilan, dan memproduksi kepuasan melalui intrinsik/ imbalan ekstrinsik. Artinya, dalam mendesain sistem blended 
learning juga mempertimbangkan teori motivasi ini karena untuk mengimplementasikan rencana susunan suasana belajar dan proses pembelajaran yang kondusif dibutuhkan motivasi dari peserta didik. Motivasi tersebut dapat dimunculkan dengan menimbulkan minat peserta didik terhadap belajar, menciptakan relevansi dengan memfasilitasi dengan media yang bervariasi dan menarik, mengembangkan harapan keberhasilan peserta didik dengan memberikan kesempatan melakukan (learning by doing) banyak hal dalam pembelajaran. Misalnya menggunakan media yang bervariasi dan relevan dengan peserta didik, pada online learning menggunakan website pembelajaran dan pada saat pertemuan di kelas menggunakan media presentasi dan multimedia interaktif.

Keahlian berikutnya atau keahlian keempat yang harus dimiliki peneliti dalam bidang desain sistem pembelajaran adalah d) memahami teori persepsi. Dalam persepsi stimulus dapat datang dari luar (menurut pandangan Behaviorisme), tetapi juga dapat datang dalam diri individu sendiri (Kognitivisme). Namun pada proses pembelajaran, sebagian besar stimulus datang dari luar individu yang bersangkutan yaitu dari desain sistem pembelajaran yang reseacher rancang. Menurut Bimo [28], persepsi dilakukan melalui macam-macam alat indra yang ada pada diri individu, media dan metode pembelajaran, tetapi sebagian besar persepsi melalui alat indra penglihatan. Karena itulah banyak riset mengenai persepsi berkaitan dengan alat penglihatan. Persepsi merupakan aktivitas yang terintegrasi dalam diri individu, maka apa yang ada dalam diri individu akan ikut aktif dalam persepsi. Berdasarkan hal tersebut, maka dalam persepsi dapat dikemukakan (faktor-faktor mempengaruhi persepsi) karena perasaan, kemampuan berpikir, pengalaman-pengalaman individu tidak sama, persepsi itu bersifat individual, maka dalam mempersepsi sesuatu stimulus, hasil persepsi mungkin akan berbeda antara individu satu dengan individu lain.

Keahlian yang tidak kalah pentingnya yang harus dimiliki oleh peneliti adalah e) keahlian memahami teori pembelajaran. Teori pembelajaran difokuskan pada bagaimana seseorang mempengaruhi orang lain agar terjadi proses belajar. Hal ini juga dikemukakan oleh Reigeluth [29] bahwa teori desain pembelajaran secara eksplisit menjadi pedoman bagaimana membantu seseorang belajar dan berkembang. Artinya, dalam desain sistem pembelajaran, teori belajarlah yang berperan untuk menciptakan suasana belajar dan proses pembelajaran itu sendiri, karena teori belajar ini merupakan kumpulan prinsip yang terintegrasi dan memberikan petunjuk untuk mengatur lingkungan belajar seperti apa yang dapat meningkatkan aktivitas pembelajaran, meningkatkan motivasi, membentuk persepsi dan mengembangkan potensi diri peserta didik. Oleh sebab itu, teori pembelajaran tidak berdiri sendiri, tetapi didasari oleh teori motivasi, persepsi dan teori belajar. Teori pembelajaran merupakan teori yang memberikan arahan bagaimana meramu komponen-komponen sistem pembelajaran agar terwujud suasana belajar dan proses pembelajaran seperti yang diharapkan. Dengan demikian, teori pembelajaran berhubungan dengan upaya mengontrol komponen sistem pembelajaran untuk mencapai tujuan pembelajaran.

Berikutnya, keahlian yang harus dimiliki oleh peneliti dalam bidang desain sistem pembelajaran adalah f) memahami teori kurikulum. Kurikulum dimaknai berbeda dari seorang orang yang mencoba memahami kurikulum, diantaranya sebagai 
lapangan, sebagai dokumen, sebagai program studi, sebagai seperangkat rencana, dan sebagai pengalaman belajar. Namun dari perdebatan ahli kurikulum, dapat dimaknai bahwa kurikulum adalah semua hal yang dirancang dan tidak dirancang oleh sekolah yang harus diikuti oleh peserta didik selama ini menempuh jalur pendidikan tertentu dalam bentuk sejumlah pengalaman belajar. Dalam mengembangkan pengalaman belajar sebagai implementasi dari kurikulum atau wujudnya dari sebuah kurikulum menurut Zais [30] dan Ornstein dan Hunkins [31] perlu mempertimbangkan komponen kurikulum, yaitu tujuan, materi/ konten/ organisasi dan evaluasi.

Terakhir, menurut penulis keahlian yang harus dimiliki oleh reseicher ataupun Teknolog Pendidikan dalam bidang desain sistem pembelajaran g) harus kreatif, inovatif dalam mengembangkan teknologi dan rekayasa pembelajaran. Artinya dengan pertimbangan komponen pembelajaran, teori-teori pendukung yakni teori sistem, teori belajar, teori motivasi, teori persepsi, teori pembelajaran dan teori kurikulum, kemampuan yang tidak kalah pentingnya adalah bagaimana kreativitas dan inovasi yang researcher ataupun Teknologi Pendidikan miliki untuk mengembangkan teknologi dalam pembelajaran dan rekayasa pembelajaran untuk menwujudkan suasana belajar dan proses pembelajaran seperti yang disebutkan dalam PP nomor 32 tahun 2013 [10]. Sehingga perkembangan teknologi dapat memecahkan permasalahan pembelajaran yang dihadapi. Artinya, pengoptimalan teknologi dalam pembelajaran tidak hanya membutuhkan kemajuan teknologi yang canggih, tetapi harus kreatif dan inovatif dalam memilih teknologi untuk memecahkan masalah belajar tertentu.

\section{4. $\quad$ Riset Tren}

Permasalahan yang sering dihadapi dalam riset desain sistem pembelajaran blended ini adalah memformulasikan campuran antara online learning dan tatap muka, belum siapnya seluruh peserta didik belajar melalui online learning, kurang memadainya fasilitas untuk online learning dan kurang termotivasinya peserta didik dalam belajar. Beberapa masalah ini masih menjadi kendala dalam mengaplikasikan blended learning. Penulis dengan tim peneliti masih berupaya dalam memecahkan masalah tersebut. Misalnya penelitian Alwen dan Ulfia tahun 20142015 [24] tentang formulasi strategi penerapan blended learning, penelitian survei penulis 2015-2016 [32] tentang kesiapan peserta didik dan pendidik dalam melakukan online learning dan penelitian mengenai motivasi peserta didik dalam belajar khususnya membahas desain pesan pembelajaran dalam blended learning untuk meningkatkan motivasi dan pemaknaan materi oleh peserta didik. Hal ini dapat diatasi dengan mengaplikaskan berbagai desain sistem pembelajaran seperti model ADDIE [33], ASSURE [34], Dick dan Carey [35], Morison, Ross dan Kemp [36] dan berbagai model sistem pembelajaran lainnya. Semua model sistem pembelajaran tersebut dimulai dengan melakukan analisis kebutuhan yang mencakup analisis tujuan pembelajaran, analisis materi ajar, analisis peserta didik dan analisis kelayakan. Hal yang sama pula dilakukan untuk blended learning pada satu mata kuliah atau mata pelajaran. Sehingga, dengan cara demikian sistem blended learning dapat diterapkan di Indonesia meskipun pada saat ini beberapa guru dalam ruang lingkup mikro dan perguruan tinggi dalam ruang lingkup makro sudah melakukan sistem blended learning. 
Selanjutnya, prediksi penulis terhadap riset dalam bidang desain sistem pembelajaran ini akan terus berkembang karena selama proses pembelajaran masih terjadi maka persoalan belajar itu tidak akan pernah usai. Seorang Teknolog Pembelajaran harus peka terhadap permasalahan belajar yang terjadi, harus kreatif dan inovatif untuk mengembangkan teknologi dalam pembelajaran dan melakukan rekayasa pembelajaran karena menurut Yusufhadi, objek Teknologi Pendidikan itu adalah masalah belajar. Jadi, dalam konteks blended learning, teknolog pembelajaran harus peka dengan masalah belajar yang terjadi di kelas. Di masa mendatang, ketika kemajuan lebih canggih muncul melebihi internet, blended learning tidak akan tertinggal. Karena seperti yang Bersin [6] kemukakan bahwa blended learning itu tidak saja pencampuran antara pertemuan tatap muka dan online learning saja, namun teknologi yang ada pada saat itu (today). Saat ini, perkembangan teknologi yang relevan adalah belajar menggunakan jaringan maka pencampurannya antara pertemuan tatap muka dan online learning, dan itu bersifat relatif berubah selama teknologi terus berkembang. Sehingga, dengan sistem pembelajaran yang mengikuti arah perkembangan teknologi komunikasi juga dapat meningkatkan interaksi peserta didik dalam interaksi pembelajaran.

\section{KESIMPULAN}

Desain sistem pembelajaran terdiri dari komponen-komponen penyusunnya, yaitu tujuan pembelajaran, materi, metode dan media, peserta didik, pendidik dan evaluasi. Seperti pada teori sistem lainnya, bahwa sistem itu terdiri dari komponenkomponen penyusunnya yang saling bersinergi. Ketika salah satu komponen tidak berperan sesuai fungsinya maka tujuan dari sistem sulit untuk tercapai. Jika ditarik ke pembelajaran, tujuan akhir dari desain sistem pembelajaran adalah menciptakan suasana belajar yang kondusif agar peserta didik secara optimal mengembangkan potensi diri. Artinya, ketika salah satu komponen pembelajaran tidak melakukan fungsinya maka tujuan pembelajaran tidak tercapai optimal.

Sehubungan dengan upaya untuk menciptakan suasana belajar, dengan perkembangan internet saat ini, sangat memungkinkan melakukan pembelajaran yang lebih fleksibel, dilakukan dimana saja dan kapan saja (online learning). Namun, belum dapat dilakukan sepenuhnya karena keterbatasan dari online learning itu sendiri. Oleh sebab itu, untuk mempertahankan pertemuan tatap muka perlu dilakukan kombinasi dengan online learning yaitu blended learning, sehingga potensi peserta didik dapat dikembangkan. Dan perlu dilakukan riset-riset yang berkenaan dengan desain sistem blended learning agar dapat memberdayakan komponen pembelajaran dalam upaya mewujudkan suasana belajar dan proses pembelajaran seperti yang disebutkan UU nomor 20 tahun 2003 [2] dan menyelenggarakan pendidikan seperti yang disebutkan PP nomor 32 tahun 2013 [10]. Untuk itu, periset atau researcher dalam bidang desain sistem pembelajaran harus memiliki keahlian dalam memahami masalah secara komprehensif, menguasai teori sistem umum, harus menguasai teori belajar, menguasai teori motivasi, menguasai teori persepsi, menguasai teori pembelajaran dan teori kurikulum serta memiliki kreativitas dan inovasi-inovasi dalam mengembangkan teknologi pembelajaran. Dengan tercapainya suasana belajar (UU nomor 20 tahun 2003) dan 
penyelenggaraan pendidikan (PP nomor 32 tahun 2013) menjadi salah satu upaya untuk menangani permasalahan pokok dalam pendidikan, yaitu kualitas, pemerataan dan relevansi

\section{UCAPAN TERIMA KASIH}

Upaya untuk mewujudkan suasana belajar dan proses pembelajaran melalui desain sistem blended learning merupakan pekerjaan yang cukup melelahkan, karena menyiapkan pembelajaran di dua dunia, dunia nyata dan dunia maya. Dalam proses perumusan blended learning Penulis selalu melibatkan berbagai kalangan untuk melakukan diskusi. Atas waktu yang mereka berikan tanpa menyebutkan satupersatu nama mereka penulis mengucapkan terima kasih. Penulis juga mengucapkan terima kasih kepada reviewer penulisan artikel ini.

*korespondensi : ulfia24@gmail.com

\section{REFERENSI}

[1] Nanang Fattah. 2012. Analisis Kebijakan Pendidikan. Bandung:Remaja Rosdakarya

[2] Undang-undang nomor 20 tahun 2013 tentang Sistem Pendidikan Nasional

[3] Tilaar. 2004. Paradigma Pendidikan Nasional. Jakarta: Rineka Cipta

[4] Cloud, Jaime P. 2010. " Educating for a Sustainable Future". Curriculum 21 Essential Education for a Changing World. (Heidi. $H$ Jacobs, Ed.). Alexandria, Virginia USA: ASCD

[5] Smaldino, Sharon E; Lowther, Deborah L; and Russel, James D. 2012. Instructional Technology and Media for Learning. Boston: Allyn \& Bacon

[6] Bersin, Josh. 2004. The Blended Learning Book; Best Practices, Proven Methodologies and Lessons Learned. United Stated: John Wiley \& Sona, Inc.

[7] Seels, Barbara B. dan Richey, Rita C. 1994. Instructional Technology. Terjemahan. Washington DC: AECT
[8] Thiagarajan. 1974. Instructional Development for Training Teachers of ExceptionalChildren. Bloomington: Center for Innovation in Teaching the Handicapped

[9] Dewi Salma Prawiradilaga. 2009. Prinsipprinsip Desain Pembelajaran. Jakarta: Kencana

[10] Peraturan Pemerintah nomor 32 tahun 2013 tentang Standar Pendidikan Nasional

[11] Richey, Rita C., Klein, James D., dan Tracey, Monica W. 2011. The Instructional Design Knowledge Base. New York: Routledge

[12] Abizar. 2008. Interaksi Komunikasi dan Pendidikan. Padang. UNP Press

[13] Shambaugh, Neal dan Magliaro, Susan D. 2006. Instructional Design; a Systematic Approache for Reflective Practice. New York: Pearson Education, Inc,

[14] Richey, Rita C.; Klein, James D dan Tracet, Monika. 2011. The Instructional Design Knowledge Base. New York: Routledge

[15] Graham, Charles R. 2005. The Handbook of Blended Learning. Bloomington: Indiana University

[16] Watson. John. 2008. Blended Learning: The Convergence of Online and Face-toFace Education. iNACOL Promising Pravtices in Online Learning

[17] Rossert, Allison. \& Frazee, R.V. 2006. Blended Learning Oppurtunities. www.amanet.org. American Management Assosiation

[18] Gredler, Margaret E. 2011. Learning and Instruction. Jakarta: Kencana

[19] Sudardja Adiwikarta. 2007. "Landasan Sosiologi”. Rujukan Filsafat, Teori dan Praktis Ilmu Pendidikan. Bandung: UPI Press

[20] Santrock, John W. 2007. Psikologi Pendidikan. $E d^{2}$. Terjemahan. Jakarta: Kencana

[21] Yusufhadi Miarso. 2011. Menuai Benih Teknologi Pendidikan. Jakarta: Kencana

[22] Kurniawati, Rita. 2014. "Pengembangan Model Pembelajaran blended Learning 
pada Mata Pelajaran Keterampilan Komputer dan Pengelolaan nformasi (KKPI) Kelas XI di SMK Negeri 2 Purwodadi". Skipsi tidak diterbitkan. Semarang: Kurikulum dan Teknologi Pendidikan FIP UNNES

[23] Luhde Irin Pradnyawati, I Nengah Suparta, dan Sariyasa. 2014. Pengaruh Strategi Blended Learning dalam Pembelajaran Kooperatif terhadap Motivasi Belajar Matematika ditinjau dari Gaya Belajar Siswa di SMP K 2 Harapan. Artikel download

[24] Alwen dan Ulfia. 2015. Formulasi Strategi Penerapan Blended Learning dalam Mengimplementaskan Kurikulum di Program Studi Teknologi Pendidikan FIP Universitas Negeri Padang. Penelitian Fundamental

[25] Atwi Suparman. 2005. Desain Instructional. Jakarta: PAU-PPAI, Universitas Terbuka

[26] Suparno. 1997. Filsafat Konstruktivisme dalam Pendidikan. Yogyakarta: Kanisius

[27] Keller. 2013. Motivation. http://www.instructionaldesign.org/concept s/motivation.html. Diakses 25 Agustus 2015

[28] Bimo Walgito. 2010. Pengantar Psikologi Umum. Yogyakarta: Andi

[29] Reigeluth, Charles M. 1999. InstructionalDesign Theories and Models: a new paradigm of instructional theory Volume II. New Jersey: Lawrance Erlbaum Associates, Publishers

[30] Zais, R.S. 1976. Curriculum: Principles, Foundations. New York: Harper \& Row Publishers

[31] Orntein, A.C. \& Hunkins, F.P. 2013. Curriculum: Principles, Foundations and Issues. Englewood Cliffs, N.J.: Prentice Hall

[32] Ulfia Rahmi. 2015. Survey Kesiapan Peserta Didik dan Pendidik Dalam Melakukan Online Learning. Penelitian Mandiri
[33] Branch, Robert Maribe. 2009. Instructional Design: The ADDIE Approach. London: Spinger

[35] Brown, Abbie \& Green Timpthy. D. 2011. The Essentials of Instructional Design; Connecting Fundamental Principles with Process and Practice. Boston: Pearson Education, Inc.

[36] Morrison, Gari R,; Ross, Steven M,; and Kemp, Jerrold E. 2004. Designing Effevtive Instruction. 4th Edition. John Wiley \& Sons, Inc 